\title{
A new approach to feed frequency studies and protein intake regulation in juvenile pirarucu
}

\author{
BRUNO O. DE MATTOS ${ }^{1}$, EDUARDO C.T. NASCIMENTO FILHO ${ }^{1}$, ALINE A. SANTOS ${ }^{2}$, KAYCK \\ A. BARRETO ${ }^{2}$, FRANCISCO J. SÁNCHEZ-VÁZQUEZ ${ }^{3}$ and RODRIGO FORTES-SILVA ${ }^{2}$ UFBA, Avenida Adhemar de Barros, s/n, Ondina, 40170-110 Salvador, BA, Brazil
${ }^{2}$ Laboratório de Comportamento Alimentar e Nutrição de Peixes, Centro de Ciências Agrárias, Ambientais e Biológicas, Campus Cruz das Almas, Universidade Federal do Recôncavo da Bahia/ UFRB, Rua Rui Barbosa, 710, Centro, 44380-000 Cruz das Almas, BA, Brazil
${ }^{3}$ Department of Physiology, Faculty of Biology, Regional Campus of International Excellence \\ ${ }^{1}$ Departamento de Zootecnia e Medicina Veterinária, Campus Ondina, Universidade Federal da Bahia/ \\ "Campus Mare Nostrum", University of Murcia, 30100, Murcia, Spain
}

Manuscript received on June 3, 2016; accepted for publication on December 8, 2016

\begin{abstract}
This study aimed to investigate pirarucu's (Arapaima gigas) ability to trigger a self-feeding system to regulate protein intake between two standard diets that contained $39 \%$ and $49 \%$ of crude protein. The same system allowed the evaluation of daily feeding and locomotor activity rhythms. Eighteen fish $(654.44 \pm 26.85 \mathrm{~g})$ were distributed into six $250 \mathrm{~L}$ tanks ( 3 fish/tank). Fish had free access to both diets ( $39 \%$ vs. $49 \%$ protein) by feeders ( 2 per tank), adapted to be activated by fish themselves. This system was connected to a computer system. After an adaptation period, fish learned to activate feeders and the mean food intake recorded was $2.14 \%$ of their body weight on a daily basis. Fish showed feeding $(72.48 \%)$ and locomotor $(72.49 \%)$ activity predominantly during the daytime, and daily variations of choice between diets, but fixed a protein intake feeding target at $44.53 \%$. These results should be considered when discussing feeding behavior, feeding schedules and diet intake regulations.
\end{abstract}

Key words: Arapaima gigas, feeding behavior, protein intake, self-feeding.

\section{INTRODUCTION}

Fish show greater variety of eating behaviors compared to terrestrial animals. Given this variability, they are considered good experimental models for studying nutrient intake regulation (Volkoff and Peter 2006). Several studies

Correspondence to: Bruno Olivetti de Mattos

E-mail: fortes@ufrb.edu.br have demonstrated fish's ability to regulate nutrient intake, such as vitamins (Oncorhynchus mykiss), zinc (Oncorhynchus mykiss), taurine (Dicentrarchus labrax), oil sources (Oreochromis niloticus), and methionine/threonine/tryptophan (Oreochromis niloticus). Other studies have shown fish's ability to regulate macronutrient intake based in post-absorptive signals, e.g. proteins, lipids and carbohydrates (Fortes-Silva et al. 2016). 
Research into fish's free choice is essential to learn fish feeding behaviors that have not been fully explored at aquaculture levels. This practice may also contribute to animal welfare as it provides animals with self-select diets (Volpato et al. 2007). This approach could help to understand the relations between feeding behavior and nutrition (Forbes 2001, Simpson and Raubenheimer 2001), fish metabolism (Boujard and Leatherland 1992, López-Vázquez et al. 2009), and also animal growth (Bolliet et al. 2000). Although several studies have demonstrated fish's ability to select diets, very few studies have addressed this issue in freshwater tropical fish.

The self feeding system, in turn, also allowed us to measure feeding activity, daily rhythm and fish's preferential feeding hours. Variation in feeding patterns may exist among different fish species and their development stages, as well as a high degree of flexibility or behavioral change (Boujard et al. 1992). For example, Oreochromis niloticus has been described as a fish with plasticity to feeding behavior and with a varying feeding period, which is considered daily for this species (Toguyeni et al. 1997, Vera et al. 2009, Fortes-Silva et al. 2010a). The self-feeding system allowed feeding to be fixed at the exact time that fish need food, which reduces the possible bias of a fixed time feeding schedule (Sánchez-Vázquez et al. 1996). Unlike manual feeding or automatic feeders, this methodology allowed fish themselves to trigger dispensing and self-feeding (Fortes-Silva et al. 2016).

This study aimed to investigate in pirarucu's (Arapaima gigas) ability to trigger a self-feeding system to regulate protein intake between two standard diets that contained $39 \%$ and $49 \%$ of crude protein. The same system allowed the evaluation of daily feeding and locomotor activity rhythms.

\section{MATERIALS AND METHODS}

\section{ANIMAL HOUSING}

The work was carried out at the Fish Feeding Behavior and Nutrition Laboratory (AQUAUFRB), Universidade Federal do Recôncavo da Bahia (Cruz das Almas, Bahia, Brazil) during March/April of 2016. Eighteen juvenile pirarucus $(654.44 \pm 26.85 \mathrm{~g})$, provided by AguaVale Fish Farming (Bahia, Brazil), were distributed into six $250 \mathrm{~L}$ tanks (3 fish per tank). The outdoor system, assembled in water recirculation, was equipped with mechanical filters, ceramic ring biofilters and $60 \mathrm{~W}$ UV light. The light intensity in the tanks was measured with a portable digital photometer (Luxímetro, São Paulo, Brazil). Fish were placed under a natural light photoperiod, with about $13 \mathrm{~h}$ of light (with threshold value of 900 lux occurring at midday) and $11 \mathrm{~h}$ of darkness ( $\leq 1$ lux). Water parameters, temperature $\left(29.00 \pm 0.70^{\circ} \mathrm{C}\right), \mathrm{pH}(6.55 \pm 0.50)$, oxygen $(7.80 \pm 0.60 \mathrm{mg} / \mathrm{L})$ and ammonia $(5.00 \pm 0.50 \mathrm{mg} / \mathrm{l})$, were measured daily throughout the experiment and were kept in an acceptable range for the species (Cavero et al. 2004). The experiment was conducted according to the principles of ethics in animal experimentation of the Ethics Commission on the Use of Animals (CEUA-UFRB) case number $\mathrm{n}^{\mathrm{o}} 23007.005093 / 2016-70$.

\section{EXPERIMENTAL DIETS}

Two experimental diets were used, one with $39 \%$ crude protein (in dry matter basis) and another 49\% (Table I), following a protein consumption range commonly observed on carnivorous fish (Gatlin 1999). Diets were extruded by the Pratigi Alimentos Company (Bahia, Brazil) and were analysed by standard Official Analytical Chemists Association (AOAC 2012) methods. Content moisture was determined by drying for $24 \mathrm{~h}$ at $110^{\circ} \mathrm{C}$ to constant weight, crude protein by the Kjeldahl method $(\mathrm{N} \times 6.25 \%)$, crude fat by diethyl ether extraction, 
TABLE I

Composition of experimental diets.

\begin{tabular}{|c|c|c|}
\hline $\begin{array}{c}\text { Ingredients (g } 100^{-1} \\
\text { g of diet) }\end{array}$ & $\begin{array}{l}\text { Diet } 1(39 \% \text { of } \\
\text { crude protein) }\end{array}$ & $\begin{array}{l}\text { Diet } 2(49 \% \text { of } \\
\text { crude protein) }\end{array}$ \\
\hline Fish meal & 29.25 & 22.46 \\
\hline Poultry viscera flour & 15.95 & 31.91 \\
\hline Soy bran & 23.00 & 23.00 \\
\hline Corn bran & 6.00 & 6.00 \\
\hline Corn grain & 14.95 & 6.53 \\
\hline Fish oil & 9.25 & 8.50 \\
\hline Dicalcium phosphate & 0.50 & 0.50 \\
\hline $\begin{array}{l}\text { Vitamin and mineral } \\
\operatorname{mix}^{\mathrm{a}}\end{array}$ & 1.00 & 1.00 \\
\hline BHT & 0.10 & 0.10 \\
\hline $\begin{array}{c}\text { Proximate analysis } \\
(\%)\end{array}$ & & \\
\hline Dry matter & 93.12 & 92.02 \\
\hline $\begin{array}{c}\text { Crude protein }(\mathrm{N} \mathrm{x} \\
6.25 \%)\end{array}$ & 39.22 & 49.26 \\
\hline Crude fat & 20.95 & 14.35 \\
\hline NFE & 25.26 & 17.02 \\
\hline Ash & 12.44 & 17.22 \\
\hline
\end{tabular}

${ }^{a}$ Vitamins and minerals $(\mathrm{mg} / \mathrm{kg}$ diet): Vit. A $(\mathrm{min})=1200.000$ UI; Vit. D3 $(\mathrm{min})=200.000 \mathrm{UI}$; Vit. E $(\mathrm{min})=12.000 \mathrm{mg}$; Vit. K3 $(\mathrm{min})=2.400 \mathrm{mg}$; Vit. B1 $(\mathrm{min})=4.800 \mathrm{mg}$; Vit. B2 $(\mathrm{min})=4.800 \mathrm{mg} ;$ Vit. B6 $(\mathrm{min})=4.000 \mathrm{mg}$; Vit. B12 $(\mathrm{min})=$ $4.800 \mathrm{mg}$; Vitamina $\mathrm{C}=48.000 \mathrm{mg}$; Folic acid $(\mathrm{min})=1.200$ $\mathrm{mg}$; Pantotenic Acid $(\mathrm{min})=12.000 \mathrm{mg}$; Biotin $(\mathrm{min})=48$ $\mathrm{mg}$; Colin $(\mathrm{min})=65.000 \mathrm{mg}$; Niacina $(\mathrm{min})=24.000 \mathrm{mg}$; Iron $(\mathrm{min})=10.000 \mathrm{mg}$; Copper $(\mathrm{min})=600 \mathrm{mg}$; Manganes $(\mathrm{min})=4.000 \mathrm{mg} ;$ Zinc $(\mathrm{min})=6.000 \mathrm{mg} ;$ Iodo $(\mathrm{min})=20 \mathrm{mg}$; Cobalt $(\mathrm{min})=2 \mathrm{mg} ;$ Selenium $(\mathrm{min})=20 \mathrm{mg}$.

ash by heating at $450^{\circ} \mathrm{C}$ for $24 \mathrm{~h}$, and nitrogen-free extract (NFE) as the remainder of crude protein, crude fat and ash.

\section{EXPERIMENTAL DESIGN}

Fish were initially submitted to a 1 -week acclimatization period to adapt to their new experimental conditions. Commercial automatic feeders (Igarapé, São Paulo), were adapted with a trigger "steel line that works as a switch" placed (3 $\mathrm{cm}$ below water surface) (Almaida-Pagan et al. 2008, Mattos et al. 2016). Every time fish bite the trigger of a feeder, about 5 pellets of the corresponding experimental diet were released (on average $0.26 \mathrm{~g}$ ). Feeders were previously adjusted to avoid overfeeding based in preliminary observations of appetite and feed intake. Feeding activity was measured as described by FortesSilva et al. (2016) and coworkers using a software to acquire data from the feeders (DIO98USB, University of Murcia, Spain). After this adjustment period, experimental diets (39\% and $49 \%$ ) were offered in separate feeders so that fish could select protein percentages. To evaluate intake, $200 \mathrm{~g}$ of the experimental diets were placed daily in each feeder. Daily feed intake was calculated from the weight considering the remainder of food placed in the feeders and the possible feed losses left in water.

Simultaneously to the feeders triggering activity, data acquired from infrared photocells (Omron, Model AD62-E3S, Japan) were recorded to measure locomotor activity, using the same software and hardware equipment. Two tanks have received an infrared photocell each. which was placed $25 \mathrm{~cm}$ from the tank's bottom. Every time fish passed the sensors, information was collected and sent to the computer (Kitagawa et al. 2015). Information was recorded every 10 minutes throughout the trial period. Thus a database was generated during the experimental period with both the feeding activity and locomotor activity rates.

At the end of the experiment, weight gain, daily feed intake and feed conversion were calculated for simple system validation purposes.

\section{DATA ANALYSIS}

The feeding and locomotor activity data were assessed by software (Temps, v.1, 179 Dr. Diez Noguera, Barcelona, Spain) to plot actograms and wave charts. Actograms were doubly plotted for better viewing. Those data were transformed to percentage to subsequent analysis. 
The diet selection results are shown at $100 \%$ with the corresponding standard error. All percentage values were arcsine-transformed $(\sqrt{ })$, which was used to achieve variance homogeneity and for the subsequent statistical analysis. Protein intake was expressed as \pm average standard error.

Data were evaluated by Student's t-test test for feeding and locomotor activity, diet selection and one-way ANOVA, Tukey test for protein intake between the days of experiment. Statistical significance was set at $\mathrm{P}<0.05$, and analysed by the SPSS program, version 15.0.

\section{RESULTS}

Although the main objective of this work was to evaluate a new feeding methodology for the species under study, in order to obtain feeding behavior data, some performance parameters were considered to validate this methodology. Fish quickly learned to associate triggering feeders with food reward. The feed intake using this system stabilized around $21.42 \pm 0.75 \mathrm{~g} / \mathrm{kg}$ body weight/ day. This consumption allowed fish to accomplish a feed conversion of $1.00 \pm 0.06$ and a weight gain of $609.44 \pm 52.46 \mathrm{~g}$ within 28 days of experiment. There were no food leftovers, which indicated that fish adapted to this self-demand system.

\section{FEEDING AND LOCOMOTOR ACTIVITY RHYTHMS}

Fish started the trial period perfectly able to trigger the stretch sensors of the demand feeders. The wave chart and actogram showed a strict daytime feeding activity for pirarucu with $72.48 \%$ of total activity ( $\mathrm{P}<0.05)$, occurring during the light phase (Fig. 1a and 1b).

A similar behavior to feeding activity was noted for locomotor activity, with $72.49 \%$ of activity occurring in the daytime (Fig. $2 a$ and $2 b$ ). The statistical analysis revealed the predominance of daytime activity $(\mathrm{P}<0.05)$.

\section{PROTEIN CONSUMPTION REGULATION}

The daily selection patterns of the two diets showed fluctuations, which alternated throughout the experimental period. Thus, there were differences in the diet selection in the days $04,15,25,26$ ( $\mathrm{P}<0.05)$. On the other hand, the fish' protein intake remained constant $(44.53 \pm 0.26 \%)$, and no significant differences were found in protein consumption for the whole experimental phase ( $\mathrm{P}$ $>0.05$ ) (Fig. 3).

\section{DISCUSSION}

The results showed that juvenile pirarucu (Arapaima gigas) used demand feeders efficiently and they displayed clearly a daytime feeding habit consistently and similarly to locomotor activity. This suggests that demand feeder methods are efficient tools to measure the diet preferences and protein intake regulation of this species. Although very few studies have evaluated the dietary behavior of pirarucu. Crescêncio et al. (2005), observed the preference of pirarucu for nighttime feeding when they fixed feeding times, however, fish showed better performance when fed in the daytime. However, given the choice fish preferred feeding during the daytime. These finding bring to light discussions on the use of self-feeding tool under experiments of food intake, feeding behavior, and in turn on feed schedule. The fixed feeding schedules in aquaculture present a bias since fish is usually feed at specific times according to the handler's convenience, which may contribute to waste accumulation and poor use of food (Cho 1992, Nunes et al. 1996, Lima et al. 2009).

The data on pirarucu feeding activity obtained herein were similar to those reported by Mattos et al. (2016), who used the same self-feeding methodology, but we also noted a diurnal pattern for locomotor activity, which was not observed in previous studies. Even though pirarucu has mandatory bimodal respiration, which implies 

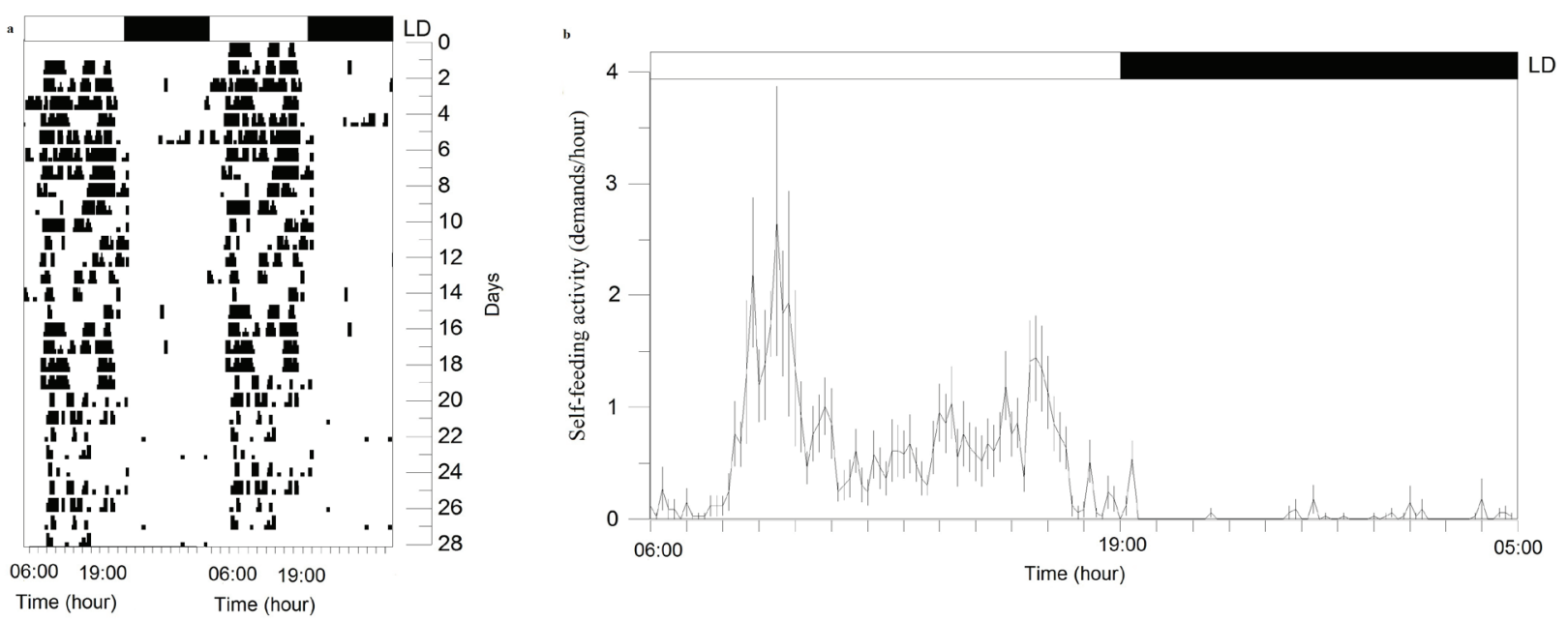

Figure 1 - Actogram (a) and average daily waveforms (b) for pirarucu's (Arapaima gigas) feeding activity rhythms measured by a self-feeding system. The white and black bars at the top of the graph indicate the duration of the light (13 h) and night (11 h) phases, respectively.
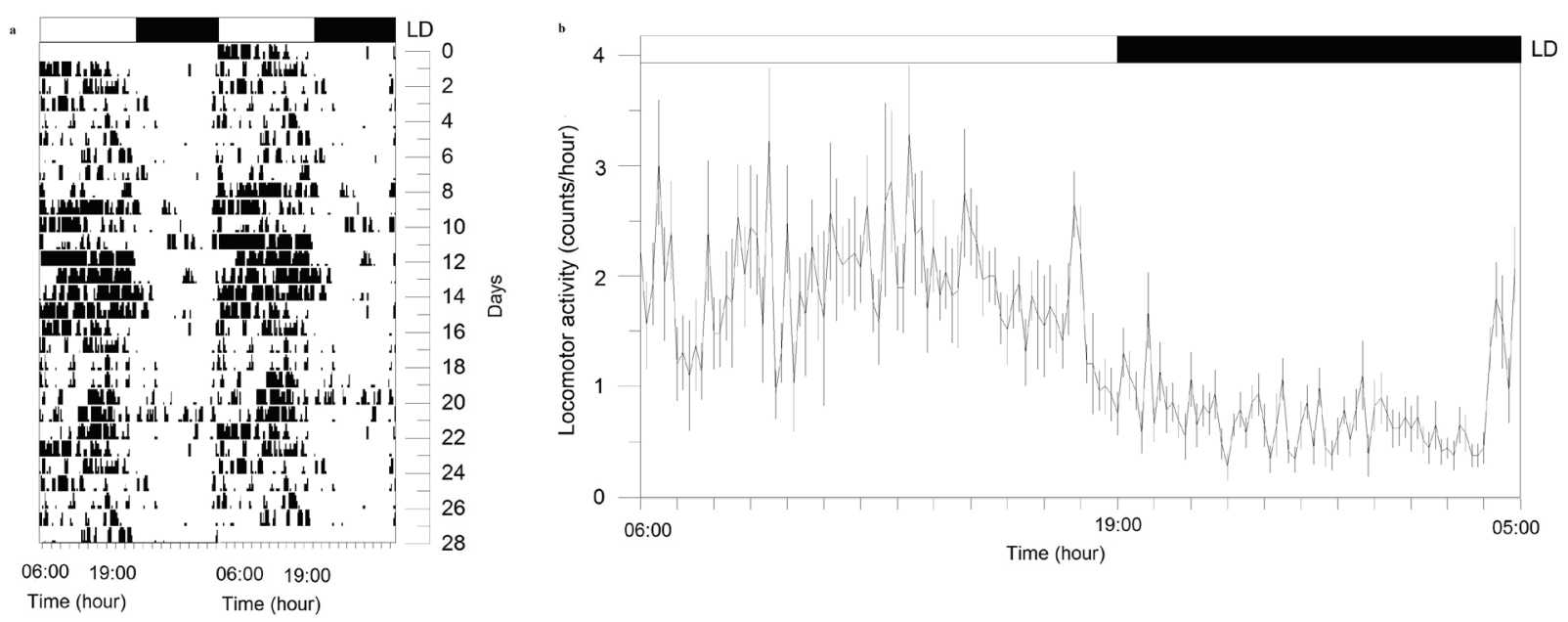

Figure 2 - Actogram (a) and average daily waveforms (b) for pirarucu's (Arapaima gigas) locomotor rhythm measured by infrared photocells. The white and black bars at the top of the graphic indicate the duration of the light $(13 \mathrm{~h})$ and night $(11 \mathrm{~h})$ phases, respectively.

having to constantly move up to the water surface to breathe (Graham, 1997, Fernandes et al. 2012, Jiang et al. 2016, Lefevre et al. 2016), the diurnal pattern noted for locomotor activity was evident. According to Del Pozo et al. (2011), zebra fish present nocturnal feeding behavior and diurnal locomotor behavior. Fortes-Silva et al. (2010b) also observed this dualistic behavior in tilapia
(Oreochrmis niloticus). It seems logical that the feeding activity pace is similar to locomotor activity. However, fish's behavioral plasticity makes them a very important experimental model.

Our results showed that juvenile pirarucu (Arapaima gigas) used demand feeders efficiently to maintain the ingested protein target. The value obtained for protein intake remained constant 


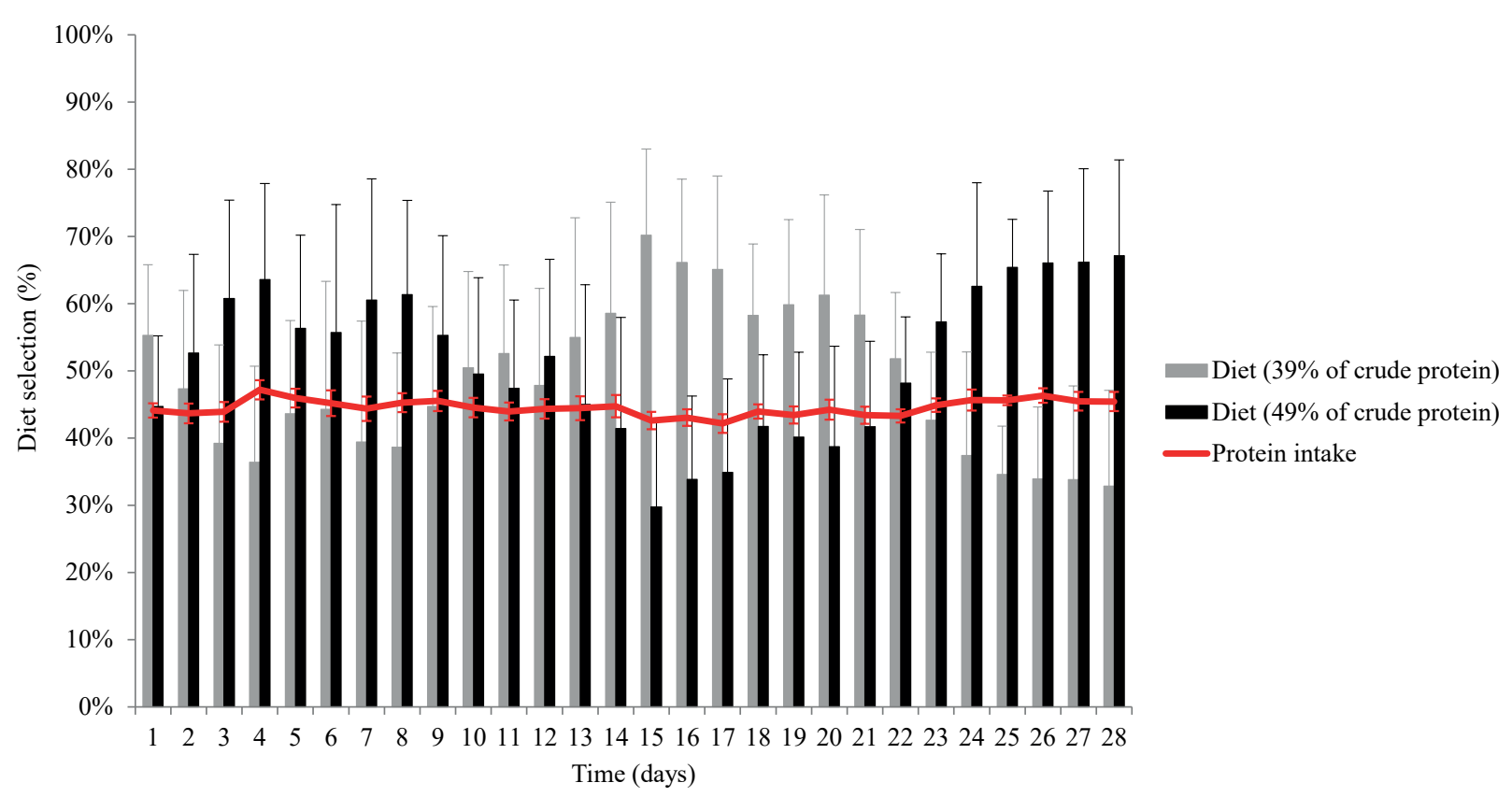

Figure 3 - Daily evolution of experimental diets selection (39\% and $49 \%$ crude protein) and protein intake. Values of diets selection with asterisk are significantly different, ANOVA, $\mathrm{P}<0.05, \mathrm{n}=6$.

throughout the experiment period, and was similar to that reported by Ituassú et al. (2005) and Del Risco et al. (2008) for the species.

Although the animals in our study maintained a stable protein intake, we observed a strong demand rotation between the different diets throughout the experimental period. This behavior (demand) can be described as a compromise rule, where animals attempt to increase the consumption of a particular nutrient, but will be subject to suffer the metabolic consequences of excessively consuming other nutrients. This effect has been described by Raubenheimer and Simpson (1999) in studies that have addressed nutritional geometric analyses, and have been applied in nutritional studies on insects (Manduca sexta L.) (Thompson and Redak 2005). Studies that have used this approach first started to do so in experimental models, such as insects. Raubenheimer and Simpson (2003) reported that when locusts (Locusta migratoria - expert in one type of grass, and Schistocerca gregaria - herbivore in general) were confined and restricted to a nutritionally unbalanced diet, they had to regulate their intake of nutrients in order to mitigate nutrient excess or deficit.

These studies are considered pioneering and are examples for other species of farm animals. The same geometrical approach in animal nutrition has been considered valid to study diet selection in fish (Simpson and Raubenheimer 2001). So when given the choice, fish have the ability to regulate nutrient intake, and to not suffer metabolic consequences of any excess or lack of essential nutrients that could condition their survival in nature (Fortes-Silva et al. 2016). Some authors call this innate ability "fish nutritional wisdom" (Rubio et al. 2003, AlmaidaPagan et al. 2008).

The primary goal of this study was not to assess fish performance parameters, but to assess the new feeding methodology for feeding behavior studies in pirarucu. However, food consumption and conversion allowed us to gain an idea about the efficiency of this system. According to Crescêncio et al. (2005), the food conversion for pirarucu was 
$1.90 \pm 0.06$ and weight gain $692 \pm 31$ g over their 60 day experiment. With the self-feeding system, the food conversion result was $1.00 \pm 0.06$ and weight gain was $609.44 \pm 52.46 \mathrm{~g}$ over 28 days. These data suggest better performance with free access to food supply. The way in which the feed is delivered mainly influences the growth rates and feed efficiency (Shi et al. 2017). According to Montoya et al. (2010), self-feeding systems allow fish to synchronise locomotor activity with metabolic and daily endocrine rhythms on the production of digestible enzymes for feeding times. Although for maximum benefit to be gained from the diet, feeding strategies should reflect the feeding rhythms of the fish (Azzaydi et al. 1998).

\section{CONCLUSIONS}

In conclusion, pirarucu was able to use the selffeeding system and showed strictly diurnal feeding and locomotor rhythms. Juvenile pirarucu used the feeders to adjust protein intake and to maintain a stable pattern of $44 \%$ crude protein. The selffeeding method can be considered a tool to help investigate food intake regulation, feeding behavior and feeding schedule.

\section{ACKNOWLEDGMENTS}

The authors of this research thank AguaVale Aquaculture for supplying juvenile pirarucu, the Pratigi Alimentos for supplying diets and the Coordenação de Aperfeiçoamento de Pessoal de Nível Superior (CAPES) for granting doctoral scholarships. This work was supported by the Conselho Nacional de Desenvolvimento Científico e Tecnológico (CNPq Grant number 477408/20133) and Fundação de Amparo à Pesquisa do Estado da Bahia (FAPESBA) (RED0004/2013 and PNE013/2014) grants awarded to Dr. Rodrigo Fortes. The authors wish to acknowledge João Lúcio Pimenta de Mattos for his kind support and assistance during the study.

\section{REFERENCES}

ALMAIDA-PAGAN PF, SECO-ROVIRA V, HERNÁNDEZ MD, MADRID JA, DE COSTA J AND MENDIOLA P. 2008. Energy intake and macronutrient selection in sharpsnout seabream (Diplodus puntazzo) challenged with fat dilution and fat deprivation using encapsulated diets. Physiol Behav 93: 474-480.

AOAC - ASSOCIATION OF OFFICIAL ANALYTICAL CHEMISTS. 2012. Official methods of analysis of the AOAC International. 19th ed., Arlington.

AZZAYDI M, MADRID JÁ, ZAMORA S, SÁNCHEZVÁZQUEZ FJ AND MARTÍNEZ FJ. 1998. Effect of three feeding strategies (automatic, ad libitum demand-feeding and time-restricted demand-feeding) on feeding rhythms and growth in European sea bass (Dicentrarchus labrax L.). Aquaculture 163: 285-296.

BOLLIET V, CHEEWASEDTHAM C, HOULIHAN D, GÉLINEAU A AND BOUJARD T. 2000. Effect of feeding time on digestibility, growth performance and protein metabolism in the rainbow trout Oncorhynchus mykiss: interactions with dietary fat levels. Aquat Living Resour 13: $107-113$.

BOUJARD T, DUGY X, GENNER D, GOSSET C AND GRIG G. 1992. Description of a modular, low cost, eater meter for the study of feeding behavior and food preferences in fish. Physiol Behav 52: 1101-1106.

BOUJARD T AND LEATHERLAND JF. 1992. Demand feeding behavior and diel pattern of feeding activity in Oncorhynchus mykiss held under different photoperiod regimes. J Fish Biol 40: 535-544.

CAVERO BAS, PEREIRA-FILHO M, BORDINHON AM, FONSECA FAL, ITUASSÚ DR, ROUBACH R AND ONO EA. 2004. Tolerância de juvenis de pirarucu ao aumento da concentração de amônia em ambiente confinado. Pesq Agropec Bras 39: 513-516.

CHO CY. 1992. Feeding systems for rainbow trout and other salmonids with reference to current estimates of energy and protein requirements. Aquaculture 100: 107-123.

CRESCÊNCIO R, ITUASSÚ DR, ROUBACH R, PEREIRAFILHO M, CAVERO BA AND GANDRA AL. 2005. Influência do período de alimentação no consumo e ganho de peso do pirarucu. Pesq Agropec Bras 40: 1217-1222.

DEL POZO A, SÁNCHEZ-FÉREZ JA AND SÁNCHEZVÁZQUEZ FJ. 2011. Circadian rhythms of self-feeding and locomotor activity in zebrafish (Danio Rerio). Chronobiol Int 28: 39-47.

DEL RISCO M, VELÁSQUEZ J, SANDOVAL M, PADILLA P, MORI-PINEDO L AND CHU-KOO F. 2008. Efeito de três níveis de proteína dietária no crescimento de juvenis de Pirarucu, Arapaima gigas. Folia Amaz 17: 29-37.

FERNANDES MN, CRUZ AL, COSTA OTF AND PERRY SF. 2012. Morphometric partitioning of the respiratory surface 
area and diffusion capacity of the gills and swim bladder in juvenile Amazonian air-breathing fish, Arapaima gigas. Micron 43: 961-970.

FORBES JM. 2001. Consequences of feeding for future feeding. Comp Biochem Phys A 128: 461-468.

FORTES-SILVA R, KITAGAWA A AND SÁNCHEZVÁZQUEZ FJ. 2016. Dietary self-selection in fish: a new approach to studying fish nutrition and feeding behavior. Rev Fish Biol Fisheries 26: 39-51.

FORTES-SILVA R, MARTÍNEZ FJ, VILLAROEL M AND SÁNCHEZ-VÁZQUEZ FJ. 2010a. Daily feeding patterns and self-selection of dietary oil in Nile tilapia. Aquac Res 42: $157-160$.

FORTES-SILVA R, MARTÍNEZ FJ, VILLARROEL M AND SÁNCHEZ-VÁZQUEZ FJ. 2010b. Daily rhythms of locomotor activity, feeding behavior and dietary selection in Nile tilapia (Oreochromis niloticus). Comp Biochem Phys A 156: 445-450.

GATLIN DM. 1999. Nutrition and feeding of red drum and hybrid striped bass. In: Chang YK and Wang SS (Eds), Advances in extrusion technology, Lancaster: Technomic Publishing Co, p. 43-52.

GRAHAM JB. 1997. Air-Breathing Fishes: Evolution, Diversity and Adaptation. Academic Press, New York, 299 p.

ITUASSÚ DR, FILHO MP, ROUBACH R, CRESCÊNCIO R, CAVERO BAS AND GANDRA AL. 2005. Níveis de proteína bruta para juvenis de pirarucu. Pesq Agropec Bras 40: 255-259.

JIANG Y, FENG S, XU J, ZHANG S, LI S, SUN X AND XU P. 2016. Comparative transcriptome analysis between aquatic and aerial breathing organs of Channa argus to reveal the genetic basis underlying bimodal respiration. Mar Genomics 29: 89-96.

KITAGAWA AT, COSTA LS, PAULINO RR, LUZ RK, VIEIRA-ROSA P, GUERRA-SANTOS B AND FORTESSILVA R. 2015. Feeding behavior and the effect of photoperiod on the performance and hematological parameters of the pacamã catfish (Lophiosilurus alexandri). Appl Anim Behav Sci 171: 211-218.

LEFEVRE S, BAYLEY M AND MCKENZIE DJ. 2016. Measuring oxygen uptake in fishes with bimodal respiration. J Fish Biol 88: 206-231.

LIMA PP, PONTES CS AND ARRUDA MF. 2009. Activity pattern of the marine shrimp Litopenaeus vannamei (Boone 1931) in laboratory as a function of different feeding frequencies. Aquac Res 41: 53-60.

LÓPEZ-VÁZQUEZ K, CASTRO-PÉREZ CA AND VAL AL. 2009. Digestive enzymes of eight Amazonian teleosts with different feeding habits. J Fish Biol 74: 1620-1628.

MATTOS BO, NASCIMENTO-FILHO ECT, BARRETO KA, BRAGA LGT AND FORTES-SILVA R. 2016. Self-feeder systems and infrared sensors to evaluate the daily feeding and locomotor rhythms of Pirarucu (Arapaima gigas) cultivated in outdoor tanks. Aquaculture 457: 118-123.

MONTOYA A, LÓPEZ-OLMEDA JF, GARAYZAR ABS AND SÁNCHEZ-VÁZQUEZ FJ. 2010. Synchronization of daily rhythms of locomotor activity and plasma glucose, cortisol and thyroid hormones to feeding in Gilthead seabream (Sparus aurata) under a light-dark cycle. Physiol Behav 101: 101-107.

NUNES AJP, GODDARD S AND GESTEIRA TCV. 1996. Feeding activity patterns of the Southern brown shrimp Penaeus subtilis under semi-intensive culture in NE Brazil. Aquaculture 144: 371-386.

RAUBENHEIMER D AND SIMPSON SJ. 1999. Integrating nutrition: a geometrical approach. Entomol Exp Appl 91: 67-82.

RAUBENHEIMER D AND SIMPSON SJ. 2003. Nutrient balancing in grasshoppers: Behavioral and physiological correlates of dietary breadth. J Exp Biol 206: 1669-1681.

RUBIO VC, SÁNCHEZ-VÁZQUEZ FJ AND MADRID JA. 2003. Macronutrient selection through postingestive signals in sea bass fed on gelatine capsules. Physiol Behav 78: 795-803.

SÁNCHEZ-VÁZQUEZ FJ, MADRID JA, ZAMORA S, IIGO M AND TABATA M. 1996. Demand-feeding and locomotor circadian rhythms in the goldfish, Carassius auratus, dual and independent phasing. Physiol Behav 60: 665-674.

SHI C, LIU Y, YI M, ZHENG J, TIAN H AND DU Y. 2017. Time-restricted self-feeding causes fin damage of Atlantic salmon. Aquacult Int 25: 47-55.

SIMPSON SJ AND RAUBENHEIMER D. 2001. A framework for the study of macronutrient intake in fish. Aquac Res 32: 421-432.

THOMPSON SN AND REDAK RA. 2005. Feeding behavior and nutrient selection in an insect Manduca sexta L. and alterations induced by parasitism. J Comp Physiol A 191: 909-923.

TOGUYENI A, FAUCONNEAU B, BOUJARD T, FOSTIER A, KUHN E, MOL K AND BAROILLER J. 1997. Feeding behavior and food utilisation in tilapia, Oreochromis niloticus: effect of sex ratio and relationship with the endocrine status. Physiol Behav 62: 273-279.

VERA LM, CAIRNS L, SÁNCHEZ-VÁZQUEZ FJ AND MIGAUD H. 2009. Circadian rhythms of locomotor activity in the Nile tilapia Oreochromis niloticus. Chronobiol Int 26: 666-681.

VOLKOFF H AND PETER RE. 2006. Feeding Behavior of Fish and its Control. Zebrafish 3: 131-140.

VOLPATO GL, GONÇALVES-DE-FREITAS E AND CASTILHO MF. 2007. Insight into the concept of fish welfare. Dis Aquat Organ 75: 165-171. 